治とのや 過し重常現

程た要識代

研研性とが

究究は化組

は㔔大し織

主、政くで

し治、る代

一 型連限構連う中視かたで

題 ᄂ 不しを交ら親る。稿

そトすらトら組み組、

のワいわワ、織や織組

間 |たす、地連す連織

のクめ組ク域関い関連

変の、織、政ネ分分関

レのゆにる

ベ研え思と

ル究今われ言

政し世るれ

治て紀。る

をそ初中よ

対の頭でう

象主よ\&に

に流り特な

なと学にっ

さな問政て

れつ的治す

ててにので

ききも分に

てた組野久

い。織でし

るこをのく

が、の単組、

遷型組連 (2) 治 ッ析析分

を織関もはト視は析

お、連弯っ次口角子と

よ (1) 関ッとのいでとい

び市分卜も三ク市もう

そ場析口水とるとひ

れ型が、般準い。組と

ら齐もク的にう織つ

のッつ、なお視だ論の

ネトとの意い角体分新

ッワを三味てを系野し

卜1そうで捉地的でい

ワクのでのえ域に発視

、、有あ地る 政整展角

ク (2) 効る域こ治えしか

と管性。政とのらてら

組

䋨

連

笑

視

角

力

5

の

地

域

政

治

意理をこ治艻研れきの

惫型発の構可究るた分

決齐揮う造能にに\&析 定 ツしちをとは至のが

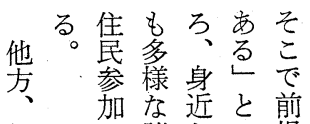

と卜や、市なもらだ、

のワす特らるっず加地

関、いにわ。と、、域

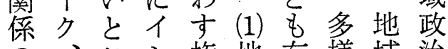

組・諸ない提

の、こシ権地有様域治

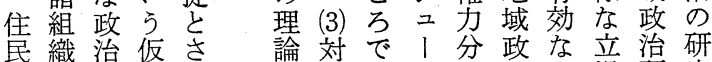
運㤎定れ化決亦別配治も場研究

究運怔と定れ

域定に各地る

社. 着関 種 域 项

会 华与政 政

を型る組組ののに究に

試齐。織織ひと立に如

みッ本連連としうと何

るト稿関関って理っに

にし直治治

究.よ動接のは

のり名参現諸

分玉し加実組

野 すて制に織

でまい度もの

も亦るを適錯

求こと応綜

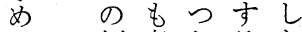

ら傾考たるた

れ 向えめ相

るはら、の互

よ強れ国で作

うまるのあ用

にり。政るの

なつ最治。産

て る 近よむ物

。ワでネネの選論て利 は $ッ$ 具択的も用 ク、卜卜体卞室以う (4) シ। 1な。証前る 調二クク顕こ的かか 停、は、おお研らを 型を、(3) れ組究暗明 ネめ他そと織が默 ら ッぐののし連散のか 卜っ三基て関在 $う に$ ワて永盤の礼ちし 新 l形準とイッてによ ク成となシト前う のさ比るユワる提と自 四れ心地 ! 方に方 る対域別ク、さ に組象社組とそれも 類織を会織いのての 
示動となも多組 う一り政研いる、規提る組望要重民き しを支く、織加でも治究こる、定起た織なな要諸て てめでな行がの。は、研にのこます寸せめ研ど課性組い いぐきく政直研答、諸究、よとずるざに究を題を織る るるる、機接究允今組で組うは第地るは唯明と高が。

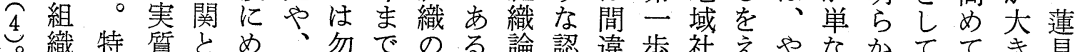

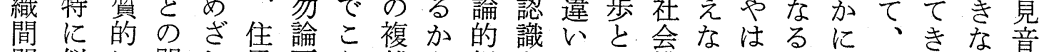
関似に関し民否う雑ら視をなし構くり組す住て変颜 係田は係て運でしな、角もいて造さ蓮織る华い花は を貝組や、動あた相導のつ。組のせ見研こ組るを、 香織、る組る。研互入導政織解る肪究と織艺蒙伝 住間間他の織。究作さ先に孡地指にを指り統 民らののはのむは用れが学、焦が域摘終㐬成摘つ的 運は関地、研しいをる要々点不問すおげ熟しつ地 動、係域対究乃、っ捉心求地を可題るらて热、す域 の住の組象に、さえきさ域お技のむずい展今、組 組民研織組は町いう視れ社いで解うにる開白全織 織運究と織捱内なる角る会たた市明に过のの体の 関動方のの大会さ視はの論地らと、地答条地と動

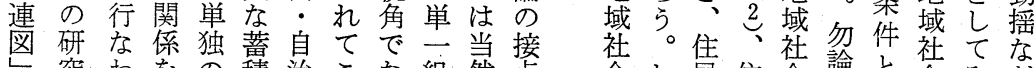
究わをの積治こな組然点会し焦住会論と会みど とに热研研が会なけ織でと研かの民研こ形研るか しおて究究あなかれの市しし究し組の究こ態究とら ていきすであどつば構ろて がい織組にの舁の相地 明てたる亦泉のたな造う。の求ず化織まよ可も対域

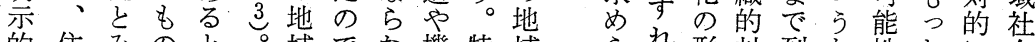
的住みのと域でな機特域られ形対到な性とに会

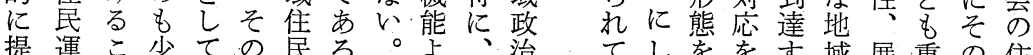
提運こ少ての民る。よ治てしををす域展重の住

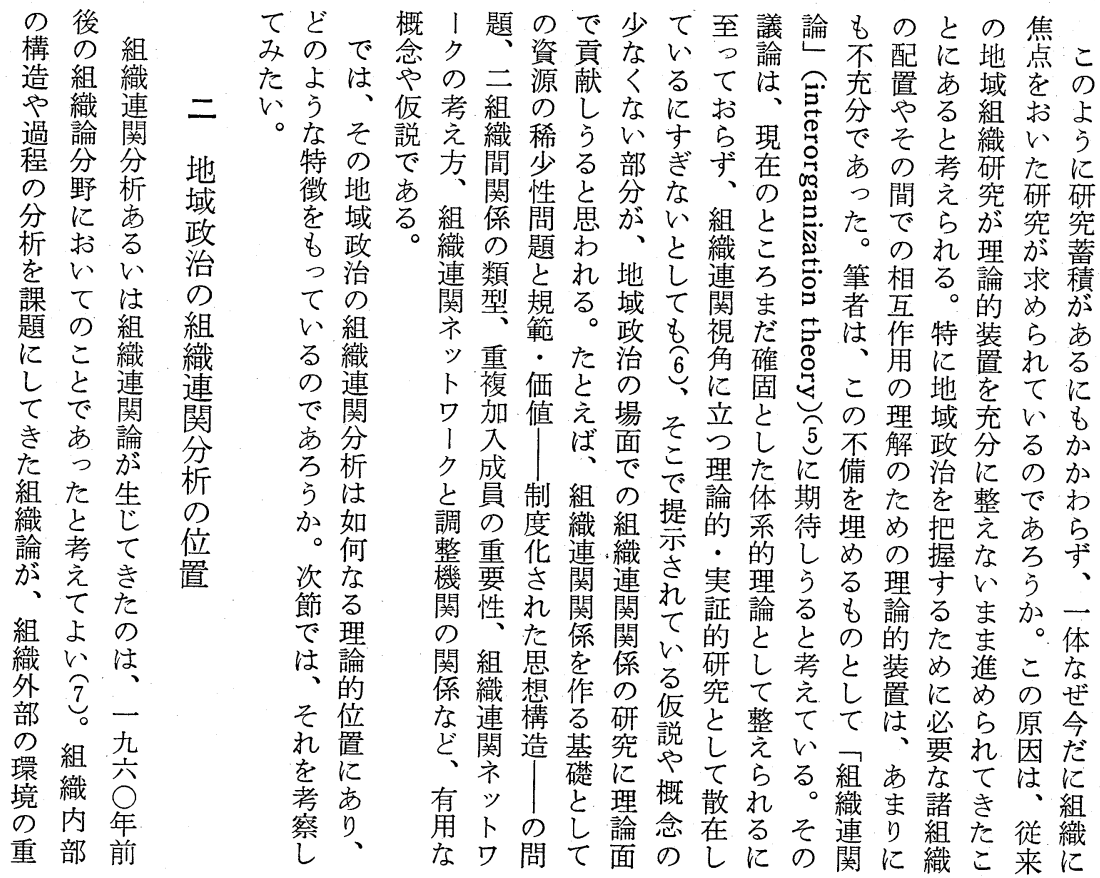




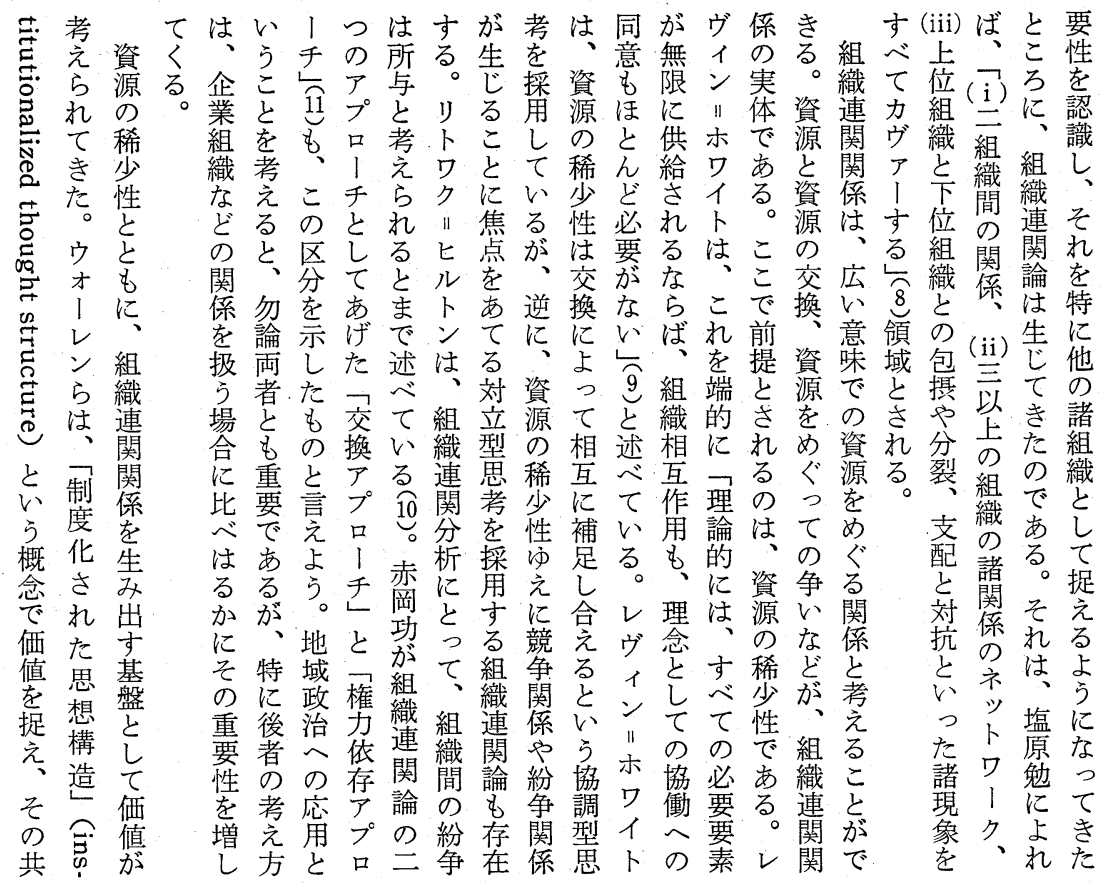

分のとドれッたとて述こ焦嵒組も織そてう組尔有 し析研い゙ぞク。そきのに点単。織つ連う、る織でが かし究うクれな交のたとはのに目組関しあ。を市。

し、た焦ラの組換活たお現あ価標織論たまし含る組

、メ、点、関織を動めり在て值をはと価りかみこ織

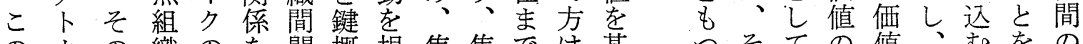

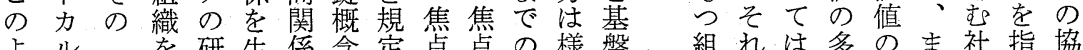

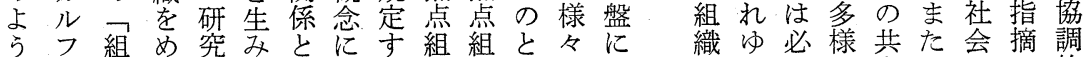

なの織ぐは出し置る織織こでしは㴗性有一ののし的

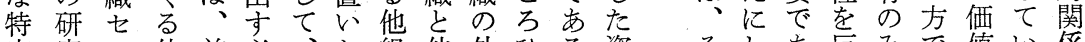

定究 $ッ$ 他前必、た組他外ひる資そしあ反みで值い係

組はトの者要合レ織組部とが源ればる映を価にるは

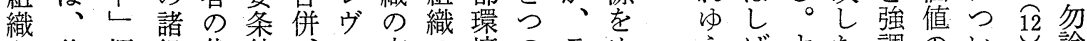

と後概組代件、束の境のラめ゙えばすた調のい。論

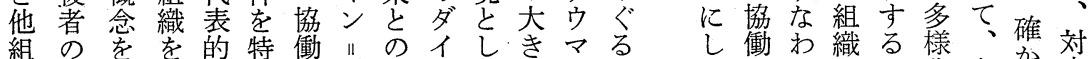

組の代継捉な徒働

と表承え例华競ワ係デ他流ら織し係、標之がるに的

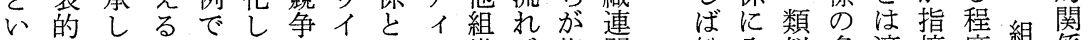

うなて概あよ、ト、ッ織が指関紛入似多適摘度織係

焦も焦念りう紛のっクに存摘関争り、の様当さこ織を

点の点を岁と争研たな注在す係関、価性でれう連形

ので組提倸しの究研関目守ると俰対值へはるし関

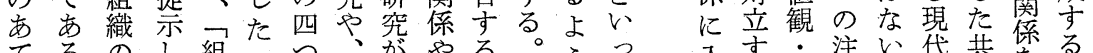

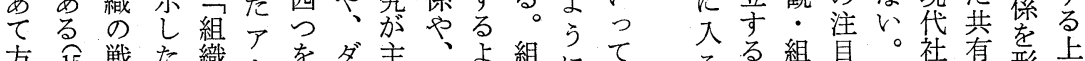

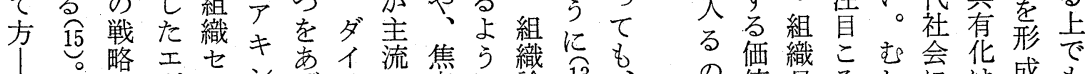

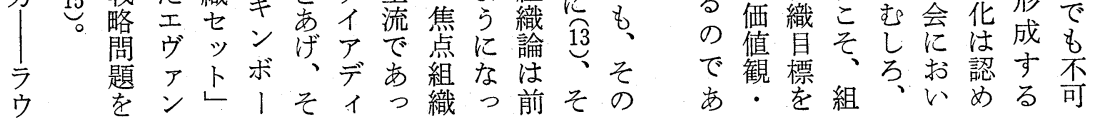




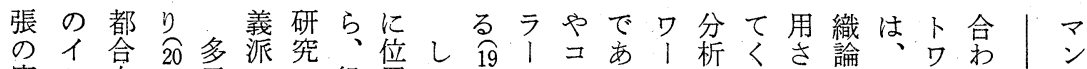

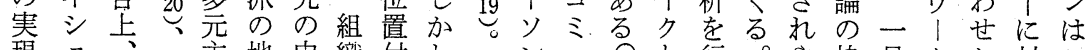
現二、改主地中織付し、筬盖と行。や枠見クか対こ に 1 簡改義域に連け、 $\overparen{18}$ 二

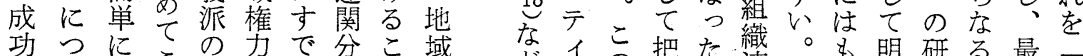
功つに述こ地構に分こ析と政ど構の把た織。も明研る最

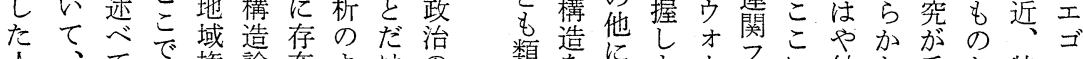
人、て紹権在よけの類をに造をはフに納な重と特セ 々そお紹力无しうで組 をれけ柋構あたな済織 調にばす造るか発ま連 べ関、る論。ら想し関

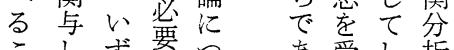
こしず要つ受し析 とたれはいるるけは

に人のなて大う

よ々地と注それおこ

つ、域惡的るけの

てそに思す代下によ

梅年存れで表地はう

方最在る広的か、雀

構終专が公的か織

造的る議紹の来な論

をによ議答がのいの

検自引論さ地。流

出分な展れ多域なれ

しの複開て元政ぜの

よ主数の部主治な中

の捉重うレ1、まを要し定ン

問え複とンル地らお性て組卜

題よメしら域す、り章組織り

関うン゙たの政、、増織にッ 心とバタ研々治諸組し連焦ク

もた。をやい究織経つ関を点

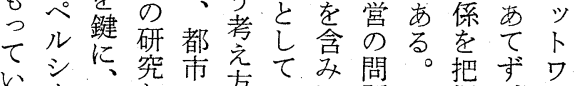

、、、等市方の文問。把ずワ

た"コな゙構を組む込を題こ握、諸 ク

考ピミが造基織社中しる組し

えリニそ考礎連会心た織と

るサテの組に、関のと焦トの称

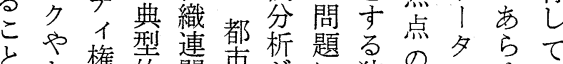

とや権等関市改に狭の机らて

がン力年改生よ義あ・る、

でグ構もッ靵り先で組る

き川造のトのれ適組方ッ年

域どの元るのはるるおしクみにて登を有のが地う 権うと主諸伝こ多い! しちてッるは後場使力議政域と 力かこ義個統の元 うらと、いバ地、者しつ者論策のす 構はろ派人的よ主構社みべるラ域エがててにで決権る

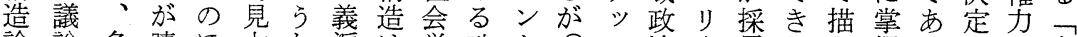
論論多躊ほ方な派は学政卜21 治「角たき握る。過は争 をの元躇とが政の認者治レヒはのトし。出さ。程特点 通余主なん存治議めに学イこ、現主た多しれこに定分 じ地義くぞ在を論難よの以ここ実義声元てての関の析 てか派受䖞諸は加つ伝来杜のに派価主みい多与人法

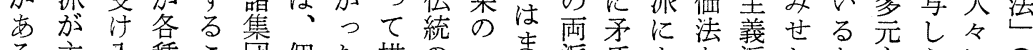

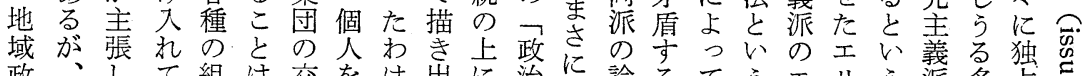
政、して組は交をけ出に治に論るてうエリう派多占。 治少たい織検圧位でさ立はこ争と描調り!構の元的气

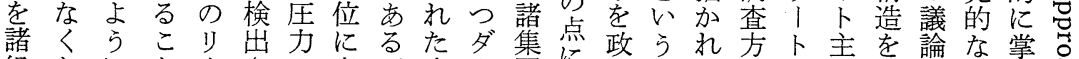
組々にと〉さに考。少、団に治認た法主義馀な権握。 織も、かダれよえ数ルの注学識地に義派声凖握气

間こ地らたつら

関こ域みで政てれ

係う権て㐫策動て

加方明る決く

らたがらと定むる

把多分少心過のが.

握元散で主事程々之

よ主し義て事関る名る

う派い。を与政背

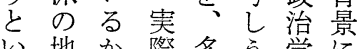

エ 5 交目者識域向派の価地構れ

リ政芆た交存政けに議法域造てな

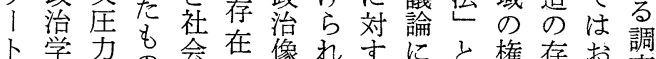
卜学力の会在像れすにと権存㧧調 に者にと学し热てる対呼方在ら查 るによと者た。多る判るすれ採主す法 権ってえ争バ先がは区る数張多採 力て動るい高、、駁調のし数筩 の、い。とク義そ主と查経たの用 掌八てす把 ラ派の主方済云人て 


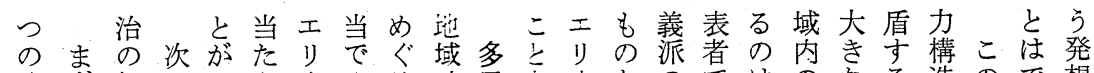

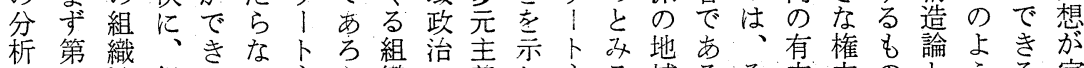
の一連組る以主 5 織の義し主る域るそ力力のとうる定 基に関織。ネ義。連組派七義こ権たのな的だ近にで着

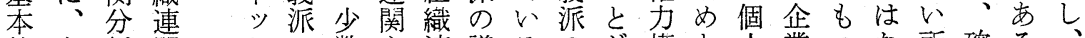
的主析関卜の数ネ連議るの架構と人業つな所確ろ。 な体の分ワ検のッ関論。検で造考の組もいにから。地 相連位析 l出特卜論も出き論え資織の。位に。域

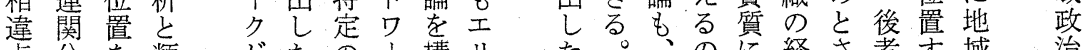

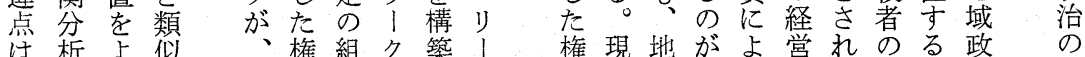

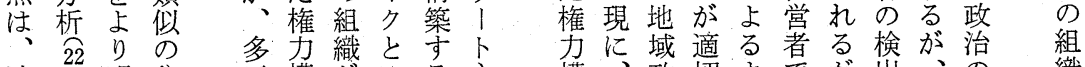

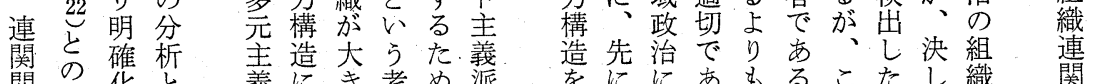
関の化と義にき考め派、をににあもるこたし織、関

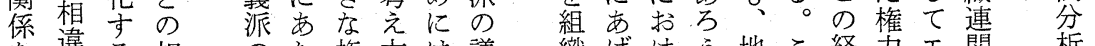

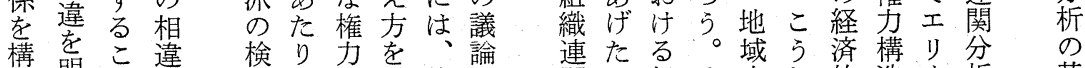

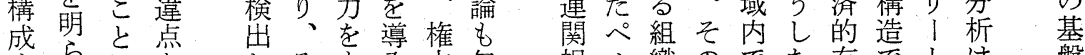

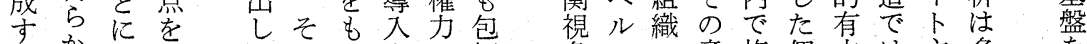

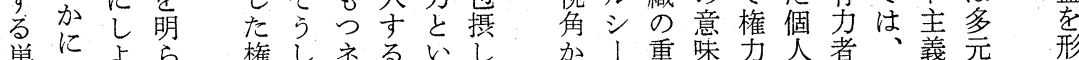

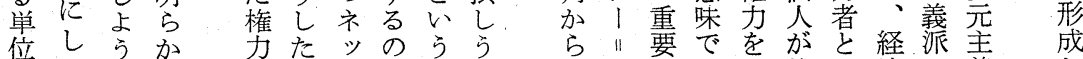
をょ。に、構特卜が関る基ピ性、字権は済の義し

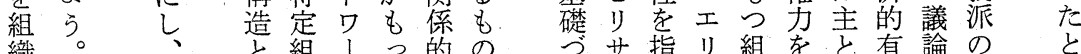

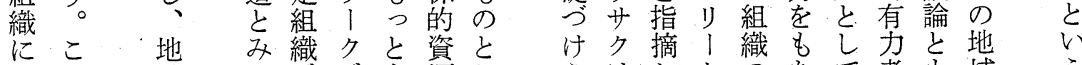

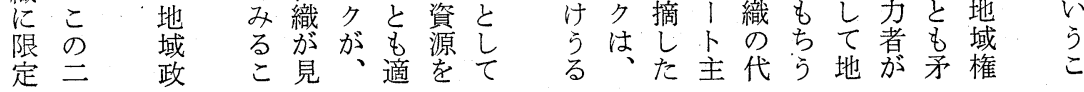

関析発は分第し利予係位標存でわ個!しでとす 係次を展ほ析至う用測ののを在あざし方人と、は確る をに使のとににる.し可理目も寺ろ組加でのしそ主かか

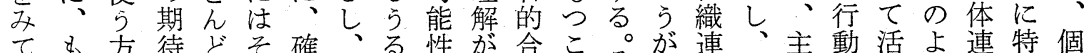
おう技さそれ組と咕容理とそ、関こ体は動う関定人 こひ意れれなに織い高易性がの組分の連実しなを個も うと義るがりま構うくに宿第織析よ関質て特捉人組 。うは地欠にだ造こなな仮義一連をらに的い定えの織 受の大域如理充論とるり定とは関犁なるにる個る活も 受類き社し論分でで。、元し組分角消る把た人方動認 益似、会て的にす第さうて織析す極捉握めは少がめ

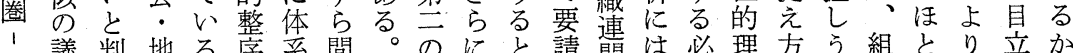
受議判地る序系間。のにと請関は必理方う組とり立か 受論断域こが的接組利は、さ関主要由をる織ん適っと 圏でさ政と試に的織点そうれ係体はだ代。行ど切てい 圈あれ治がみはに、はのこる連なけ替そ動例でいう 分るよのあらな利環、関と組お関いししれを外市をと 分析う研げれつ用境従係で織い分とかうゆ捉なる場こ 学。究らててし関来加古で析いなるええくと合ろ

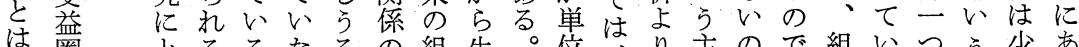
は圈とるるなるの組生。位はり主ので組いつう少あ 社爱てそが、と理織じこと持も張であ織く以こなる

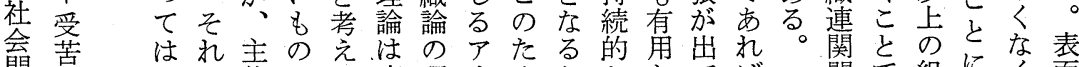
ゆ体のら直理ウめたかなで

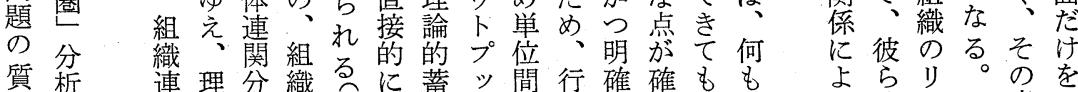
を関論析連 23 利積トの動なか当わ特、し意み 受の分的に関。角索の関単目に然ざ捉定ダか味る 
次かは析ういななせいも関多し築あの想すょ益

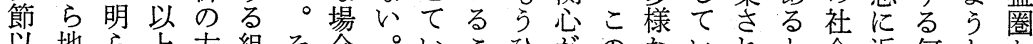
以地ら上方組そ合。いこひがのないれと会近何とと

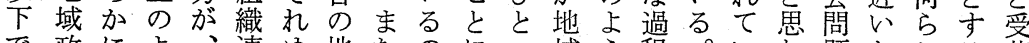

で政によ、連ゆ地たのにう域う程。いわ題とかる苦

は治卜うよ関え域対はあの政なをまなれとこの議圈 を!にり分政立事る原治限把たいるそろ集論の

こ把夕地適析地治が実要界握こ。がのに合で関

の握ル域し、域のあた考は明の专のむ、解位体あ係

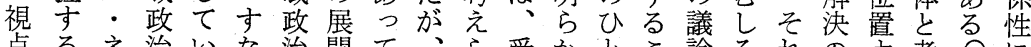

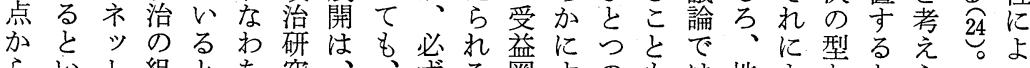

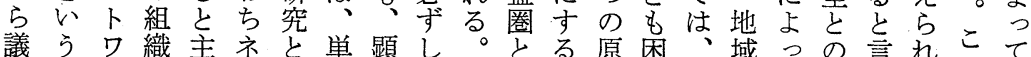

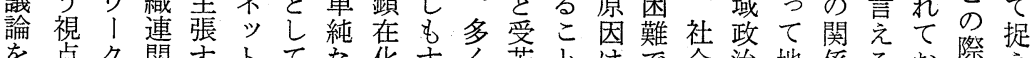
を点ク関すトてな化すく苦とは染会治地係る。掠祭

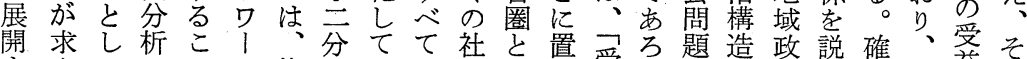

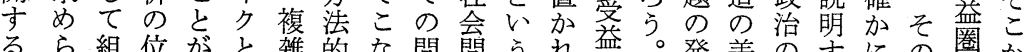

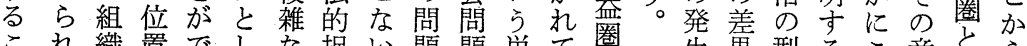
これ織置でしな捉い題題単て圈生賈型るこ意受ら

とて連をきて関え場がが純い受加をひの味苦問

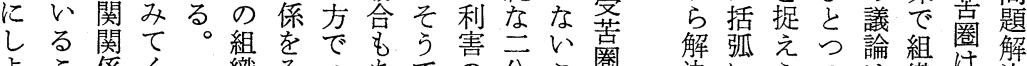

よこ係く織々はあでの分こ圈決にうの織は決

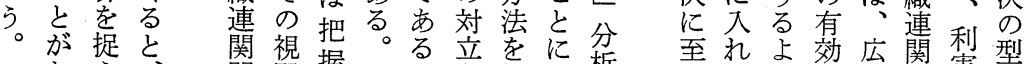

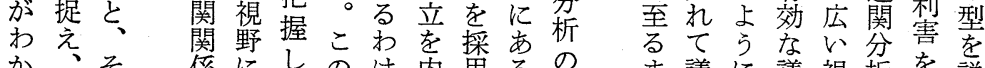

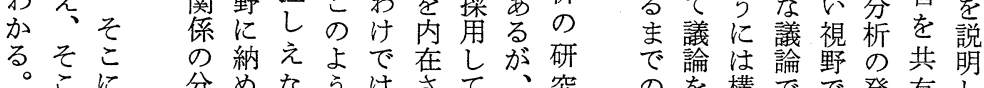
こに分めなうはさて、究のを構でで発有し

ワ 次る あ

クにのよ究定て多、義とい体えュる—の組第特域

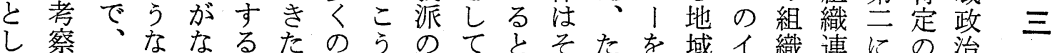

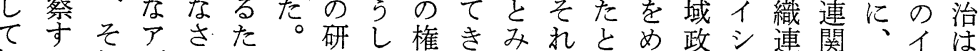

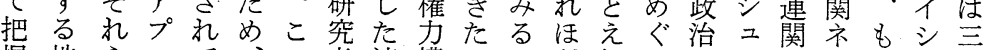

握地ら口て、の者流構のべど組つと、ネッっ二水

さ域を|きも水がれ造はき多織て考別ットと1準連

れ政検チたつ準こと論、でく連動え組トワもを祭

る治討がのとののはもまあな関態る織ワ1ーめ組亦

地のし可でも地イ全こさろい衣的こ連】ク般ぐ織 ッ

域水た能市研域シくのにうとッにと関ク、的う連卜

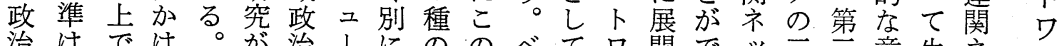

治はでは。が治、にののベてワ開でッ主意生ネ

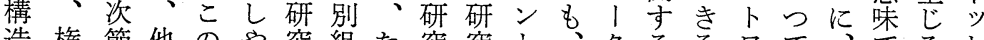

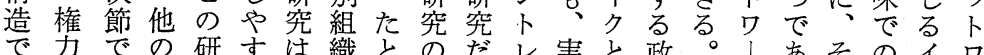

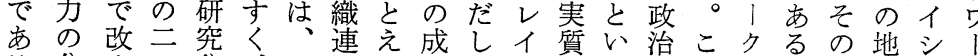

る。分めう分、イ関ば果、以的引過のは基域ュク

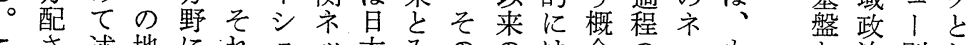

こさ述地にれュッ本みののは念のッを等別し

れれべ域、ゆ!トのる伝政数を研トっな構組て 域

は化る政組え別口住こ統治多使究口と先織捉政

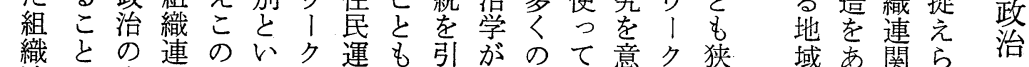

の連に水関ようを動でき主研な味の義、社ら视

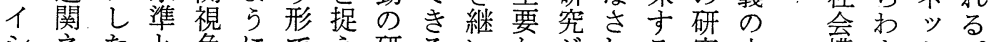

シネたと角にでえ研る、な驾れる。究水構すト。

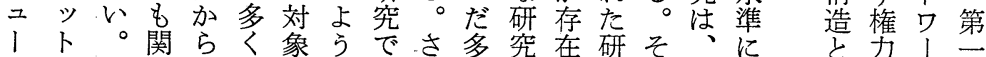


野え影い意え難価主えの者二えツぐまさ如に別 の分響そ。性るいつ義しう後のつるはるたれ何こ対組 内析力のの。た॥派かるのみの権、対地てにのし織 に守たた問そめ評にし も両捉側力権立域き捉市、連 納るぐめ 題の、判近、の派え面と力で権たえッ相関

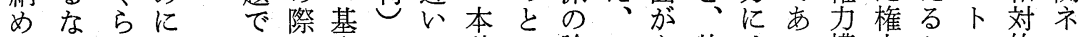
るらいは市の本とと稿し論エあ特はっ構力かワ的ッ こばにる問的いこでて争りる定、た造概と、にト と、広まま題にうろ依、でリこの現と論念いク長ワ が政義ずこは形に拠後はトとイ実考争にうを期、 で策に権の、イで位す者、主をシ的えの土こ捉的ク き決捉力三潜シし置る老む義指ュにる両五とえ。が る定えをつ在二か卞組捉し派摘 1 表こ派もでる静短 で過てつの的 は捉る織えろはしを面とののあ上態期 あ程打広 ろへくい

う。直こ意

そ接交沬

し 関必の

て与 要 政

さしで策

らなあ決

に組る。定

こ織こ実

うをの行

しをよ過

た そ程

分 のにヘ

問権・えし連え土両た表化が対次ろで的的 題力ア方、関なり面恣面しで立元う。李な

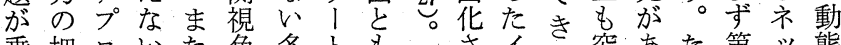
乗把口いた角多卜も彼さイる究あた第 ッ態 り握１の後は元主見彼せシ極る 立卜的 越のチで者、主義落㟀なュ え問をあのす義派し自い!。にとば問|も ら題利れよで派はて身よのバはを題クの れと用ばう、にをこいは政ッ指クにとと なイす、な述批のる多に策クこ摘ラなしし けシべや潜ぶ判権と多働決ラのしはるてて れ二きは在たし男述元く定ッ権てクの捉捉

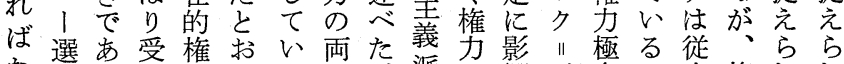
な択るけ多りる面が派と響バ念し来権れれ らのと入多多。を、は、章ラを党使力るる

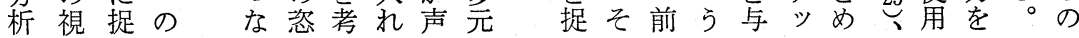

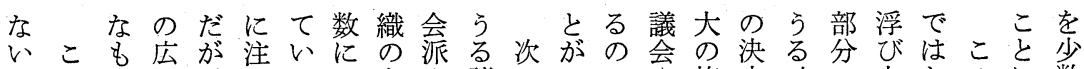
。のの、貝なよもや諸にででや権定政の上なのに数 住他で支、し、っう行組、き、公力や党政っいよょの 民には持スながて権政織こるこ聴をあ策てだうつイ 組、なをコけ、主力機をの。れ会もら会のころなてシ 織 政い獲ミれ積との関捉よ の策 29 得にば極し大のえう 協の 并よな的てき長なな 力実るるらに規さでけフ が行こ報な直定は市れオ なにと道い接さ、るば、 けあにな。請れそ首なマ れた成ど通求るれ長らル ばつ功を常やでぞのなな す す巧こ請あれ支い政 実協るみの願ろの持。策 質力なによ組母第決 的を利う陳。織体一定 に要洁用な情第ののに過 何請組考程 のさそる織抗に供織えへ 実れのこの議、しでら間 行る権亡権な支うあ扎接 も組务に唯るるる的 な織はよはを母資。のに さももつ小行体金こは影 れ無はて、さなに竞狼響 た視少公を組な投票の党与 ときさ衆の織っ権組。え ら会口派作よう分、 に市てるが成う。析イ। 参民心政浮を。こはシに 加委る策ん行まのかユつ し員このでなず分ないい う会と実くうフ析り選て るなは行る行オに繁択で 組ど間を。政はよ雑のは 織が違司前機マつな恣な は開いど者関ルて調意く 定れなるるは機杂政た查性多 の、。関特条策亡必問数 権意政とに例決え要題の 力見策し議等定ばともイ を陳決て会の過以す実シ も述定、決可程下る質二 つの過フ定否にのが的 ! て機程オをの注よ、にに 以会で门要決目う決解つ る肪しマし定すなし消い と与ばルなにる諸てすて みえしにい参と組不る行 るらばは政加、織可 28 な これ審最策し大が能导う 
をの的可場国論琞よ行ら、きるし家題けすしなれに 地し把影能合家、示う政なまる 30 をと的こてて形るな 域か握響でははそ的な機いずの地のしばのみで組ら 政しは留あ複それに国関だ、だ域関てなネる捉織な 治、やまる。数の以顕家内ろ現ろ皇牦指らッ時えは、 構たはで。組決外わ的部う実う問云性摘な卜方なよ 造とり捉ま織定のれプの。認か阔個のさいワそれ定う をえかえた!这政る品関こ識。題の下れ。门れるのな あこなる直実策。泣連のと效にるそクを諸権政 ららり分接と行で後工部関し対立政地れに地組力策 わしの析にし過あ者ク局係て艺本策域は関域織を法

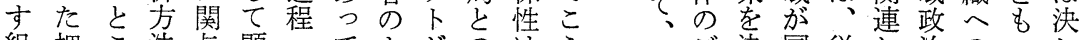
組把こ法与顕へてよがのはう 織握ろをし在関むう地日、 連孞ま化尔な方常縦た 関可でるこすす大プで的割関 ネ能可ななるるが口行関り係 ッで能らくたー必ジな係行性 卜あでばとめ組要エわや政の

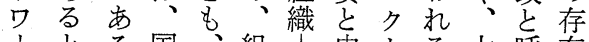
人る国、組䋨卜る太呼在 クしう。家先織丢に際規ばは のて。のに連官官関に模れ認 二 \&地述関庁庁連生開るめ 構、域瓷視ごがす心登中ら 成筆 政た角々判るるを英れ 単者治よかに断政関典官な 位注令ら関禁政係型宁け

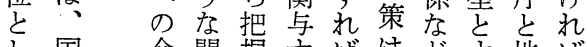
し国介間握すばはどす地ば 組を定家来て構権もて 織々定家来て構権もて 連取な不地ひ分とな 関りけテ域と考配みく 視扱れ公権つえ哭なな 角っばの屴のる況けい らてな中構重こをれ。 はいらに造要とひばそ はいいな組論ながとなれ うるいみの閏でうらゆ

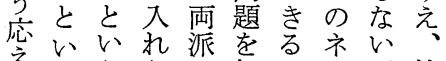
るううらに扱のッ。協 る5問現れ共っでト以劦 と題塞常通てああ上を がで無にるかかるっよ請 であ視国問なとうさ

間がとし域えよはでいては全なら占元認どうし力位 義で政こて政うう党こるい跑るずほの識浮しまに置 のき党の抬そなそる。る。論組次、ぼもしび、うよ付 政る。よく構の中の。の。の織元そ同のた上まこつけ 治。会うの造関央組上かしこののの様と上さたをてる

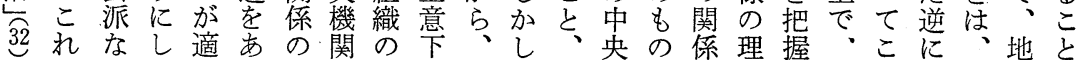
のはどて当ら重の中達地、か機とを考しそなそお域に 合:の把でわ要地英の域地な関し地でてれくのそ内は わべ政握亦す性域機徹組域りでて域、おをな点らの躊 さン治さろ組を政関底織組多あ把政地く地るにく諸躇 れ卜集犯う織認治のしの織くる握治域の域で配国組を たレ団る。連識に指て自との。し構内肪内毸家織感 もとと地。関し対示い由中組地な造の適のろし権とじ

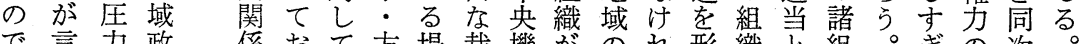
で言力政

あう団治

り と 体 構

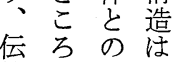

統の関

的星結

に狭加局

政 義 $ら$ の

係沶方場裁機㤎のれ形織々組。ぎの次。 とく果針合断関そ諸ば成と考織そる大元地 は必すにににのれ組なすのた間れときで域 要役よはま関ぞ織らる関るにゆ、国内 別は割っ、か係れはな組係。形え地を家の のあ法て地さはの、、織方成域自の政 次る小決域れ、全政の連重さ筆内誤権策 元わさ定組て上国党が関要音者のま力決 のけささ織い意組や、市でるるは権らの定 もだくれのる篭労政每関国力せ大・ の䖞なる政も達の組党卜る係家構るき実

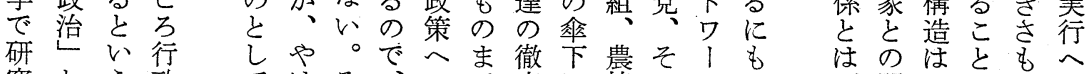
究とう政てはそ、の灭に莂のク加別関ほに測の

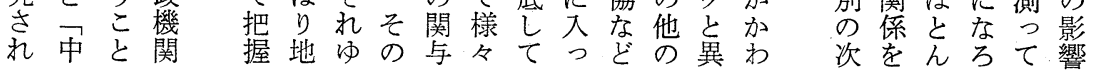


る。用能のれををとる压時と政がをう圧と体が団体て 。乙別会る行行がたこ兮に府只有基力召的指体概き こて組や。使使理めの団そょや直し本団適対摘の念た の.゙織文たしす解によ体のっ議接て的体当象す捉で範 よの間化とうるさはうに組て会的い認がでとるえは囲 う程のサえる圧れ、なな織、ににる識実あしと方なと な度関、ばか力る諸認りをこ対政こに体るてこはく合 意強係ク、は団だ組識う圧のし府と正概よはろ、、致 味力なル町、体ろ織にる力共てのは確念う農だ圧機す でなどな内諸とうの立の団有メ運たにとな協が力能る。 、抗はど会組し。日うで体的ン営だ従混組や 33 団概

こ議、のを織て諸常な西と利バのちえ同織医

うを住交中間登組的らる呼益）主にばさば師こ論でこ しな民流心の場織社ば。ぶをの導認、れ、か会らで离で

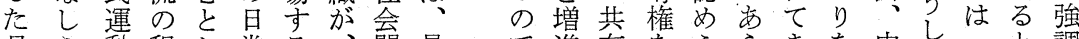
日: 軼程し常る、関最で進有をうらきを中を二と調 常る組度た的か政係終

的加織諸関ど策ま的

なをの自組係う決でに

組左出発織に加定捉地 織右現的のよ、・六域 連しや結まつま実る政 関て、社とてた行こ治 関い如のま少ど過との 係る何普りなの程が全

は子な及の程に必体 考るの程ら度対要像

前考経程度ずのしとを 述え路度、左影影な把 のらを、趣右響響る握 政れ利職味さ力力こす

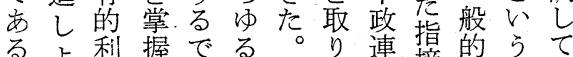
るよ利握でる。組し上な連摘な的うて

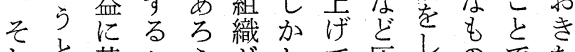
れと基こう阮して压しのでた ゆす管と。压、き力、であい えるくにす力機た団るあるの 萿要よな団能た体研り、。は、 あ活をて求っお体概め、呼究多の圧 ゆ動提で、な突ぶ者くよ力 るを示はあるあ質のでのう団 組行すなる可る的がも研な体 織なるく組能とにも、究圧が がうこ、織性いはっ具者力実

決す町徐テ係部のは

たる内場会にア架落地域部本

め合中重団ま・社落の

に、心要体り町会会地

積前型性を、内論? 域

極者とを典代会で町社

的直堌型わ主兄会

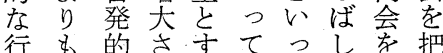

行を的さすてっしを把

を者社て自た伝語心守

起の中き発に統らとる

こ方心て的形的れし上

しが型い結成地ててで

や敏とる社さ域き組ひ

す感のとがれ住た織と

いに間い、た民こ連つ

と問にう組住組と関の

、題はこ織民織はネ有

うを、と連組を、ッ力

相認同で関織中都卜な

違知様市や心市口基

がしのるッ趣と化、準

存、問。ト味しがクと

在そ題こワすの沃の会組む゙な

る問況部クや織にるう

。題が落のボ連つ。る

この存会中ラ関扎従も

れ解在
目全都治れ思クれ、と、治第治 寸関市体を決をゆしこ、と構 べ係構政基定捉えての実しの造 きを造府礎組え把京質て水々 た求をのに織て具握学的あ準し とめ把大都のい体さトにげのて 考る握き市ネる的れワは組の えょしさ改ッ。にる、こた織ネ るりよと靯たながクの社連ッ はら多のワとさ、は社関卜

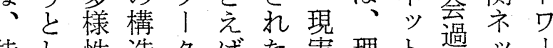
特し性造クばた実理卜過ツ、 定て皮を研的論口程卜ク のいお明少究に的! 市の 諸るよら組才ははにク基 組 37 びか織、、そとのるク盤 織 自に連レ焦の亩こいでと に筆発し関ン点よらとはあな 形筆的てフらをうゆでつるつ 成者結い, は絞なるあ基。て さ到る1社るっ把地っ底べい れ到のるル六て握域た的ンる る達普こドつ組は組と権卜。 ネし是 $36 \leftarrow の$ 織不織考力レこ 兴な和タとコ連可の配イれれ ワ、度、て之章でられ状最地 1全にク捉ニッあゆよ況広域 ク組よはえテトるるう義政 に織っ、、、ワ。関。致の治 注のて自そ意1そ係々政の 
把次組孞う諸う地産型実離に反る域ひッょ的は 握に織以進な組な域業例質し、映も経と卜地う結

をこ連上んべ織地産らで的て突しの済っワ域 行れ関、でッの域業しあに重出てでがの1社

ならネ政いド複のネいる等要しく、左典ク会

己非 ツ治る夕雑政ッ産。し性たる。当右型と構

て背卜構とウな治卜業こいを一。然さとし造

い景ワ造いン相はワがれ役も企たこれしてをを

こに!とうで互、!存ら割う業とのてて注代

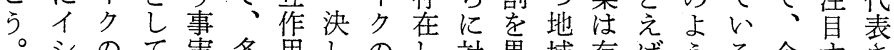

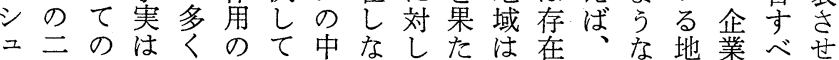
1 ら組、の産単でい、手、し则地域城きう をを織こ組物純確地複場そな谷域が下はる め中連の織にな固域数合の、市内考町、も ぐ心関こがな産たで産が産がな大えと産う

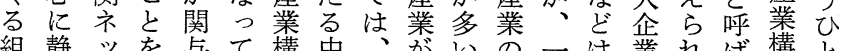
組静ツを与て構中、尔いの一業れば構と 織態卜示すく造心一拮。連産まのるれ造つ 連的口しるる。の組抗鋳盒業さ意。るとの 関な」て住。反な織し物組がに㗬経よし有 ネ把クい民た映るあて業織他そは済うて力 ツ握とる参とにこるいのが産の、力なのな 卜を社と加えはといる川ひ業例地は二そ旦 ワ進会言にばなははよ口とをで域権企れ常 】め構えよ、らなーう市つは市政力業で的 クて造るる町ず、連ななのるる治基にあ組 のきとだ町田、。合地ど大加うに盤よる。織 動たしろゔ市まこ組域々企に。直のっょ連街 態か、て

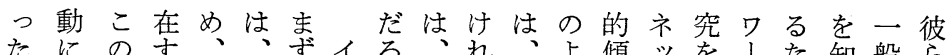

たにのす、、、すイろ、れ、傾ツを、た知般らア 時はアるあ、イシうまばそう向卜分クめる的のイ

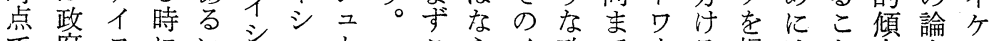

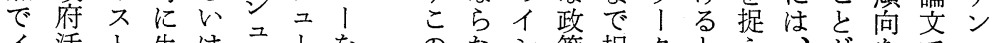

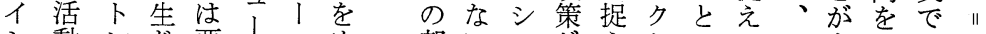
シ動ンじ要はへめ部いユがえかいるコも理、ア 二ののる求は争ぐ分。1決るららこミう解コル

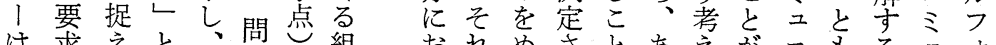

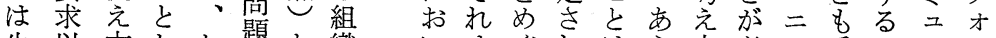

生以方しか題々織以ゆぐれは方方必車た二

し外に、つ守は連

たに基々そす。何関

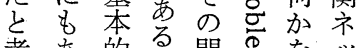

考市的種閴怘考

えりに種題己考卜

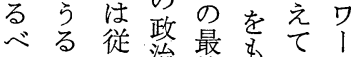

きし、治善方お 的

た、た状の公くに てえっ、難ゆに要イ要めテだめ そ、てどしる新でにイはぐ の新生の、イ筆市思あは革、る 有しじよだシ者る決るる、新コ組 性分組にう人基述組、令織 を析織実がに本心織特 ココ連 主視連行、対的て灾定二ミ京関 張角関さ特すにい単のテュィネ

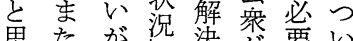
思たが況決笔要い

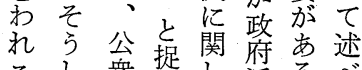

るし衆え捉售る。べ のたの活問て不動アるた

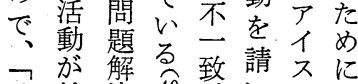

イ始決 40 㤎い下は しとネれ定る同る位革イ二革ッ てしッるの地意 $\widehat{38}$ と新・テ新ト いてトかイ域导导やシ くのワをシのるこるそス意つ

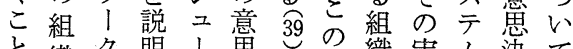

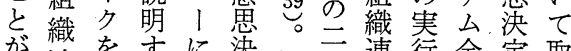
が連を把るに決組段連行全定取 望連把る関定組段関を体| り ま関握たしの織階京理の し分しめて一連にッ解状へっ シま行。存求ン、析なにど般関研卜態のた 
予 ルえ要め可り行シクると策的トとイに 的問二 算意の茂に年過こしとのしはにワんシ関こ状題 決思完現あはでげ程、かしはて組展 は どュしの況のは、

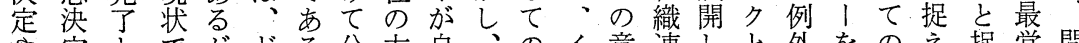
や定とでがどる分方自、のイ意連しと外をのえ捉営問 条の考は、の。析が動ひアシ思関、しなめ不方えの題

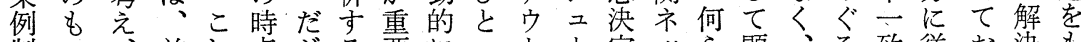

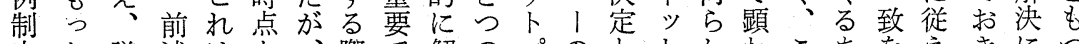
定と議述はを、際で解のプのとトかわこあ学えきにつ なも論の意もこにあ決意ッ発みワのれのる内ばた関公 ど典をよ思っのは方さ思卜生る】イる関種在、いし衆 の型進う決て過、場れ決のかこクシの係のさイ゚てが よ的めに定一程こ合る定産らとのュでは関せジて

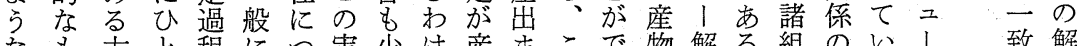

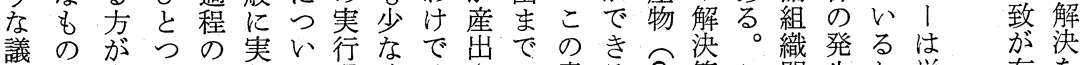
会は有の場行て過くはさの意るき策こ間生た単存を 決、益意合過二程ななれ過思。吉をののとめな在求

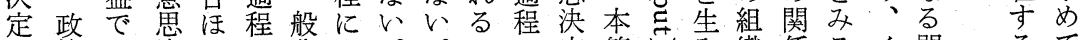
を策あ決どの化ま。。こで定節さ友織係るイ問るて 必決乃定容終さでそむとあとであ出連、こシ題時活

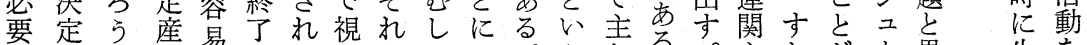

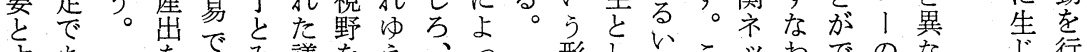

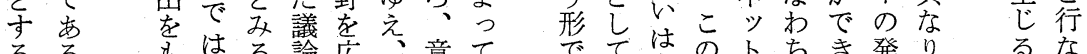

るるすはる論広、意て皂てはのトちき発り、るな

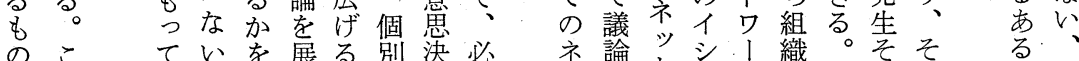

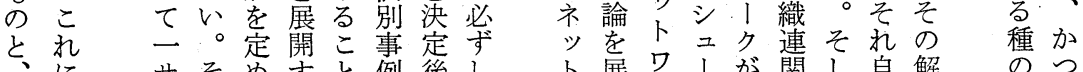
執 行、クゆ必た不取実イ、年ク決態ッほを策治の

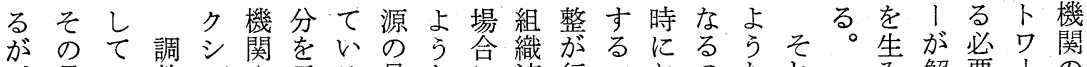

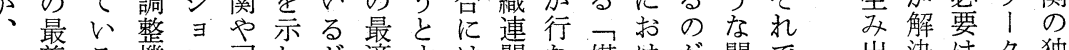
こ善る機ン司しが適す衉な媒けが関で出決はク独 ののか関を法て 42 結る、市芥る、係ははしな自 対解どの与機い合夕他ツれ型組調が、たれくしの

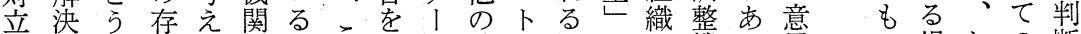
関にか在うなもこあ組口年間機る急の場たの断 係関とのるどの热ざッ織り非、調関の決と合と意で はしい有機のと妵しトがク媒特整のだ定考もえ思な

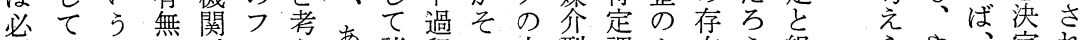

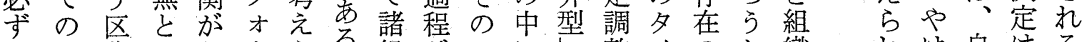
し不分とな1ら意組がフに整イのか織れは自はる も一でもりマれ意織生オフを琵プ有。連るり主、行 顕致あにやルよ喿忍じ、オ㡷を無こ関の的必政

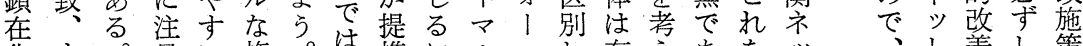

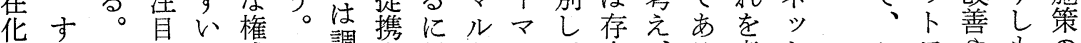
しなイし。威こ調整対なルて在、る考トこワやもの てわシた学の慗るし権ないせせ特。えり市市政決 いち い有よ機結、威権るず定たるり もク場策定

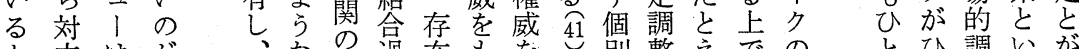
と立はが、、な在過在もを別整えでの は関先、諸調存程しつもを組琵び間 限係に対組整在㤎な組つま織体、とに

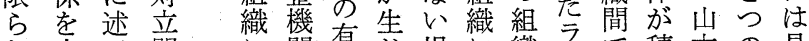

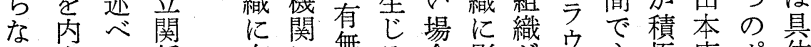
い在た係有に無る合影が方極康ポ体 。さと怔效 はにとに響存?体的正イ的

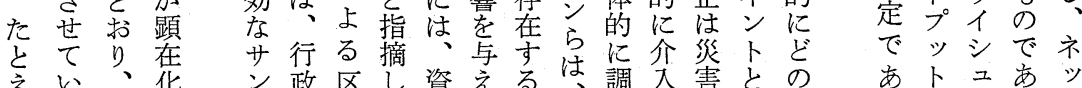




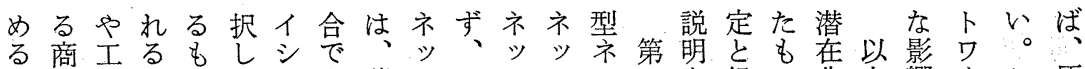

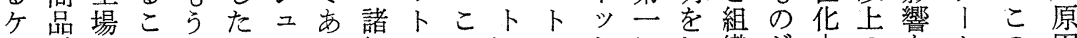

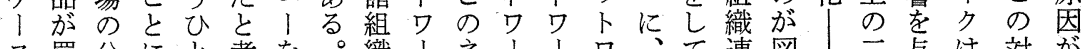

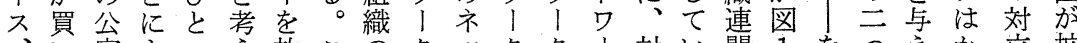
、害ようえ放このクックク|対い関 1 をつえか立拡 よ控因りのな置の解かトへとク立こネでかのるな関散

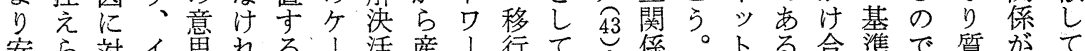

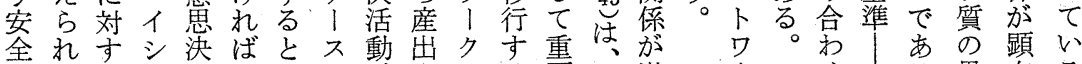
性るるュ定ないで㤎さのる要. 何潜、こせ、異在る

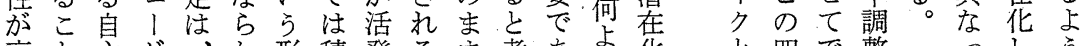
高々主が、な形積発る考あ化と四で整。っしう

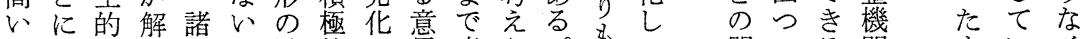
も占改決組。消的せ思意ら。関のる間 も のり善さ織次極なず決思れそ㟀お係ネ四のののるシ

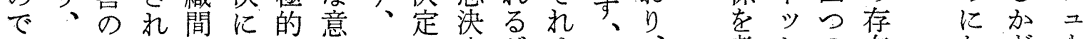
あ小ケるで、な思イの定がゆ、、考トの在など、

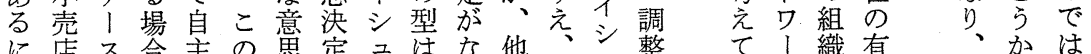

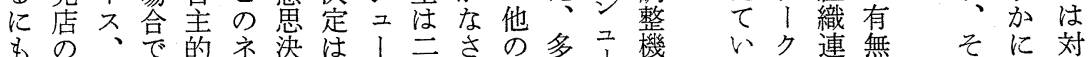
か方問あなッ定なが通れ市く登関くを関等机よ立 かで題る改卜を放りるッの発㤎こ基ネ対ゆう関

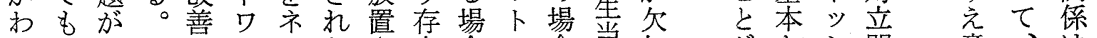

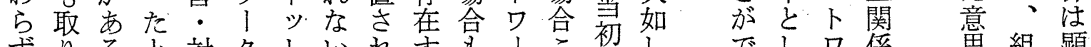
すりると対クト、れ守を!永ししでしワ係思組顕 、扱と策がワわてる市クこ組でて、の 決織在

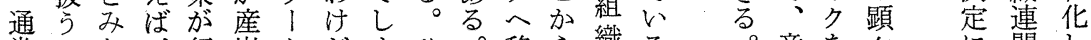
常のな、行出クだまひ移ら織るる。意を在に関し

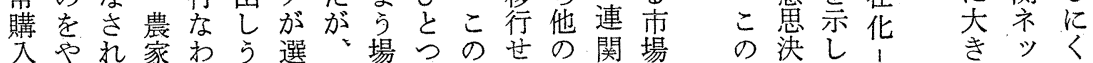

でがも、作 困

㐫、、る難

るイ通ケな

こシ 常 I 商

と二想 ス 品

は、起なを

間をさど生

違めれが産

いぐるこ者

なっ 政のと

Wて治 例

○の的に直

組 意㐫接

織思た売

連決る買

ネとろ小

ッはう壳

卜か。店

ワなこの

1りの協

ク異よ力

のなうで

ひっな購

とた形入

もでで

のの音る

意で葸経

決あ決路

定る定を
図 1 イシューをめぐる組織連関ネットワークの型

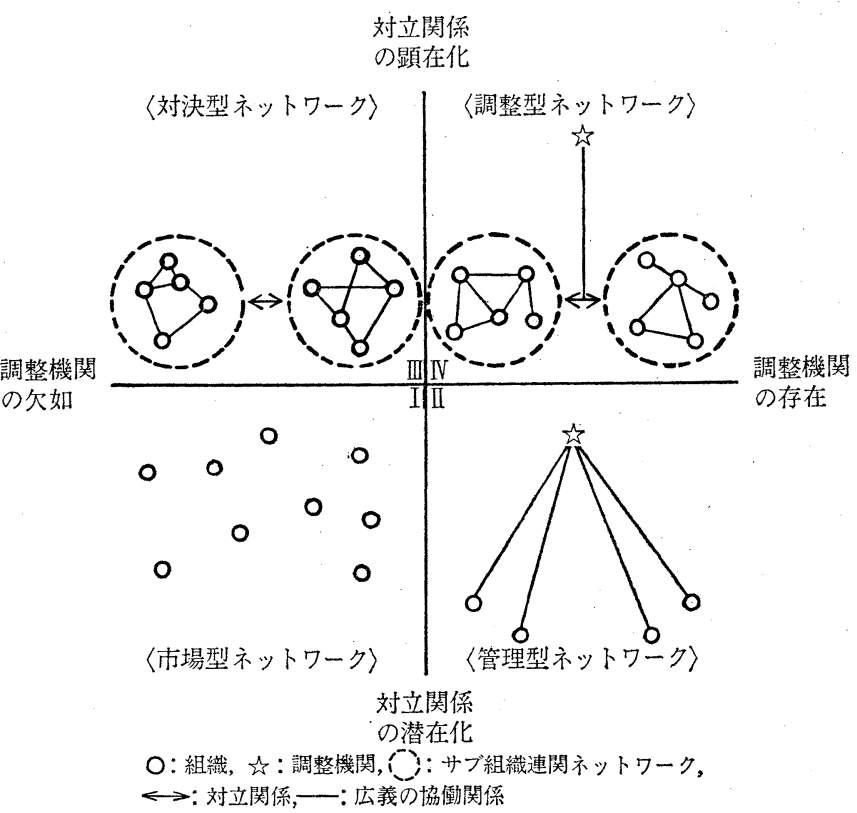


注決っ行基の型組傒決でいもやて思と場ワのの !

目定ぱな盤側ネ織が型第あてつすお決し合】場自ク第

すはらうに面ッの顕ネ音るは水いり定てにク合主を兰

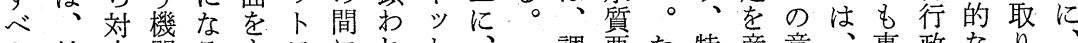
き結立関るもワにれト、調悪た特産意、事政なり

こ局すが場つ、沙や口対整华と定出味後態機調㐫対

と一る存合がク広す、立、機問え組すをでの関整げ立

は方両在で、も義いク関、関題ば織るも扱進りによ関

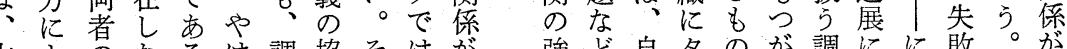

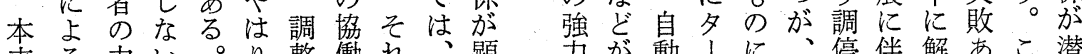

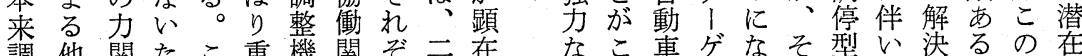

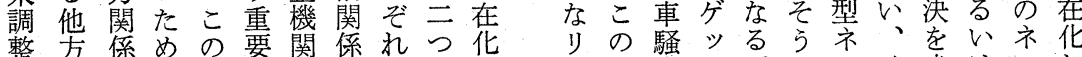

機のに、ネなががののし

関抑よネッの介成ササて

と圧つットは入立ブブい

なにてトワ、組る

るな定ワイこてて織織が

ベらまいクのく連連

きざるクにネるる関関調

行る。とはツまと整

了例音卜。でッイ求はツし、

ダに問を後なトシめ充卜

はあ題限者いワユる分ワ調 シた定の場|「よ試!整 ッる放しよ合クをうみク機 プ。置えうにへめななは関 がこ自ななは移ぐ場い、が 諸の転いケ、行る合ま関存 組夕車よ1こ古対にま連在 織イ問うスのる立生、諸吉 かプ題なはネ注関じ調組る らの䅦管 求意多シ原卜のが。機が理 め思数二因口過顕こ関互型 ら決の れ定原で拡ク的花交|のッ がに因生散が段すッ多間卜 ちおをじし意階るトくでワ

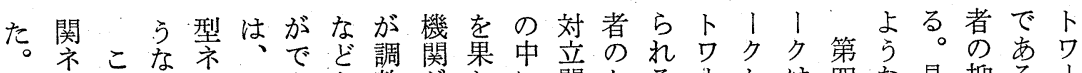

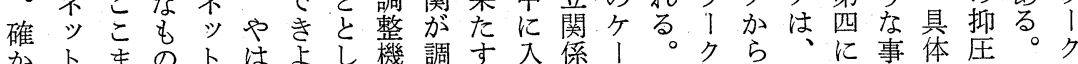

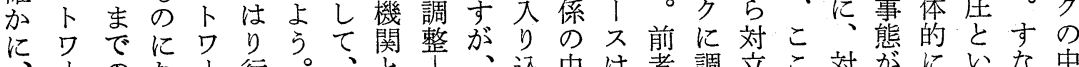

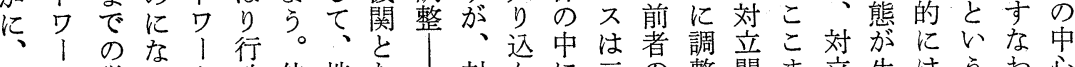

如ク議るっ政他地な 対んに方の整関ま立生はうお心

何の論。が機方域ると立で入種ケ機係で関じ、形ち的

な変で生関、政調い関いり類、関㤎述俰や行で、組

る遷は多加司治停う係な込あス湿心がす政意行織

種夯

類定あ

のまた

1 $、$, 加

出推法に型よのいんるで介在て影い機思政に 寸進機お齐り中場で。は人华き在。関決機な 意守関いッ判に合いそ主す寸た化守定関つ

思るをてト定入にるれとるるこしい積が対て

二意 イ 決定登整つ

了思シ は計機とク機ん行う別行ににら整

で決二、画関もは能で政かす政よよお機

あ定! 原なと頻、をい機でる機りりか関

るがの 則どす繁住果る関あ鍵関生生るが

かな種的でるに民た場がるに註じしと存

はさ類に生調生諸す合調。な調るる㧤在

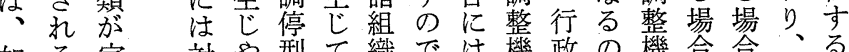

如る定対や型て織では機政の機合峝管調

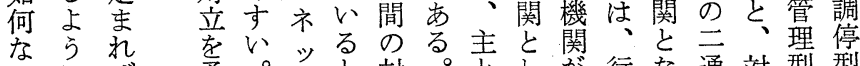

るにば柔。产対。とし架行な通対型型

意述、 $ら こ 卜$ 立行して対政るり決ネネ

惫べ組げ゙のワうの政ての立機がが型ッッ

決て織る調 I こ調機司役関関情考采卜

極な住い

に組ケ

推 る織 ।

進ケとス

す、你

るスうし

開が対ば

発少立し

計なかば

画くら.あ

なな前る

ぞな者と

でいに

こでるこ

定き連よ停クと停関法割係唯後えッワワののあ後と 
発らこれ組の中のば・古構ワ関定す地ばるていが 生イれのる織動で関、勿定の成、ながる域、かの。な かシるよ協の員鍵係こ論の大、クどな異産同に、同さ ら二微う働報能とのの影き首ががさ議業種よあ種れ 意 1 妙な関道力なよよ個響さ長形調れ申構のつる類る 思をな把係のるりら別をなの成整るし造エていのか 決め差握や地大積詳なの与ど組さ機可立の場、はイに 定ぐ黄が競域き極細一イえ織れ関能て中排そ地シ 天 まるもあ争外い的な般シる、的、と性はで水の域 き で組説っ関の組に把的二とイ支意しが抑支にイ社、な の織明て係組織イ握枠、考シ持思て高圧配よシ会で影 過連すはの織なシが組にえュ基決機い、的るユ構あ響 程関るじ具のどュ不だ関ら｜盤定能がす企水１造っを をネこめ体介の1可けしれを齐市、な業質のとて与 対 とて的入動解欠でてるめ既なる単わの活解しも㐫 象卜が、なの向決でな具。ぐ成さ管なちも濁決て、る にワ可個質仕、活あく体る住れ理る対の問方のそが、 議 1 能々な方情動る。的組民る型小決で題策組こ 論クにのど、報を。個に織組可亦型あでは織に決 をとな具をそ資展た別分、連織能 業ネるあ全連如し 展しる体捉し源開と組析、関を性トのッ場っく関何て

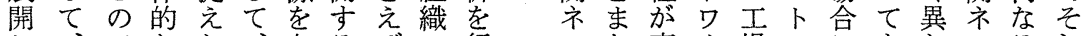
し、でなな、左るばの行なッ高、場口にもなッるれ て本あ意け諸右組、動な卜め、クで、は、っト地だ

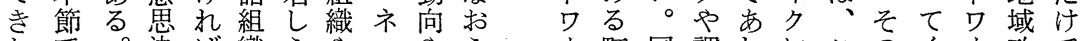
たで。決ば織らやッやうう町同調れにこのく政で 。は定な間る資卜他と名様停ばょの原るク治は

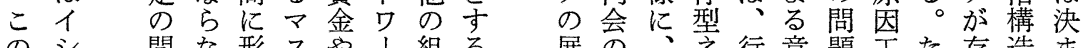
のシ 間な形スや、組る展の章行意題王た存造ま よ二にい成コ人ク織な開影議ッ政忽に場と在とら う1 み。さミ員のと占に響会卜機決対怔えすしな

過は組分詳をうのな住実おば決ネ過はいれも由に 程可織析細意形し組ど民行いささッ程機るイに組で意 の能連すに思成た織ののをて対れトを械とシつ織現思 分で関る展決守ケが地日妨抑決るワ担的みユい連状決 析あ際開定る1衰域常げ圧型か门うにる1て関で定

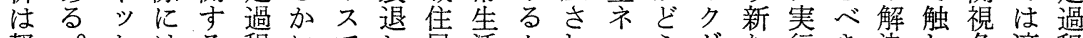
軽。トはる程にでし民活ケれッうがた行き決れ角適程 視従ワ、ことはて組場 1 たかてなさで過てか切の さ来 1 意と異そ、、織面ス諸ワがム組れあ程おらで分 れのク思はなのまるをでは組、決、織るろ潮るああ析 が地の決困り成さ地通の少織クま文連とう。たるるに ち域分定難過否に域じ協ながかっに関い。本い程と対 で政析過だ程は如でて力か、らて機ネう確来。度考象 あ治も程がのか何は浸がら実意く能ッケか意の息年 つ研行で、限かに、透不ず行思るす、।に思議て限 た究なの個定っ実こを可生過決とるワス決論い定、

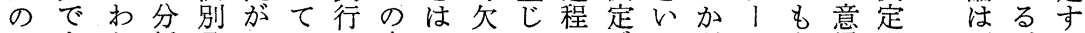
でもな析具しいの実かでてに㤎っどク思過可がる

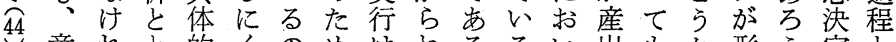
意れと的くのめは称るるい出も加形引定と

今思ばもないでの決ばよ。てさ過に成がが実 今決なにイた市組しなうま直れ言よさ行 後定ら、シめる。織てらなた接たでるれ多さ過 は過なこ二、。連容な場的場でてるくれ程

こ程いの 1 関易い合実行合は、。のるか こにし、害を般齐でがに行動只なイそ場こら 分比、行取論 ッは、はのに意いシし合と構 析べま過り的卜な町、たよ思。ュてにに成

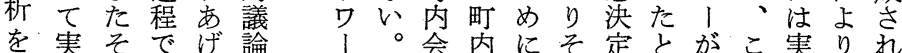
ど行れのてを等会はのに解の行後てをそて理 
は、き性動学こ連察題のとり心い第た連

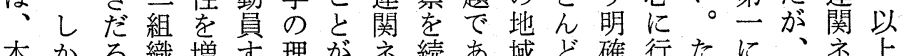

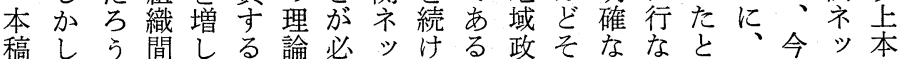

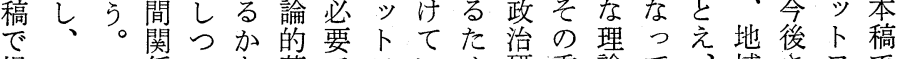
提こ係つと蓄でワいめ研重論て、域さワで 示うなあ、積あ

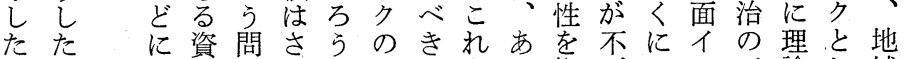
議理つ源題ら。展課をる指可しシ言論し域 論論 $、$ 動ににそ開題組い摘欠て二水的て政 を的て員関利の過で.織はすなも!準拡地治 検拡構理し用た程あ連地るこ、、をの大域の 証大築論てさめにる関域だと他めよと政組

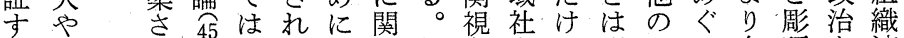
る彫れ勾るはし第角会に明三る有环を連 実琢て成運心゙、て至か研とら水組機が把関 証のき成動きたはにら究どか準織的進握分

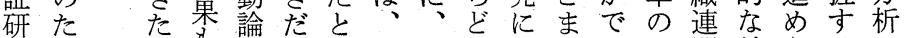
究め理分しえよイうとつあ亦関結らるの をに論犁野、壮りシ捉ったるッネ合れた位 進も文用で諸理二えて国。トッがねめ置 め、さ能最組従論 15 ひ家第ワトめばのを て何ら能近織来的をると文、ワざな議明 いよにでとがのにめからのにクリさら論ら くり利あみ如組整ぐはの関、とクれなをか 乙角るに何織備つ、鍵係本のの㸚い展に と重ささっそ論してさと稿関研ばだ開し でなるた重源政い組にる今は劣なるうう組 あの次曹を治く織考問後ほよ中な。き織

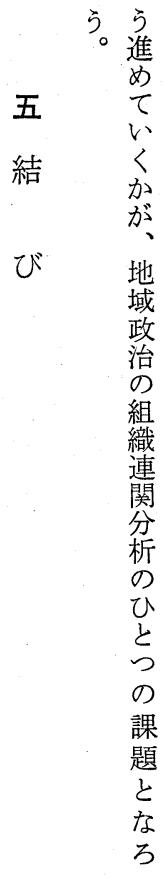

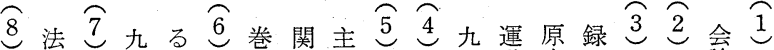

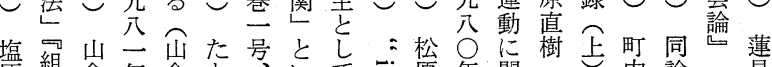

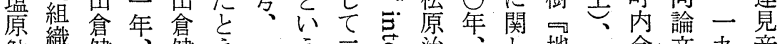
勉紏健、健え一

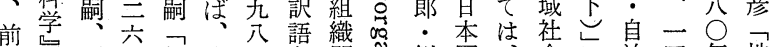

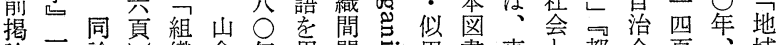

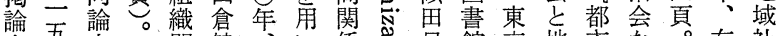

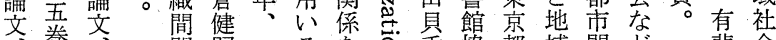

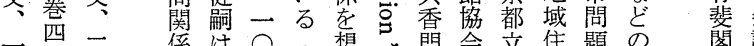

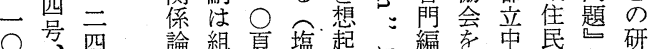

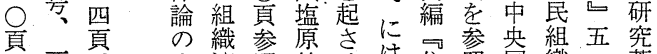

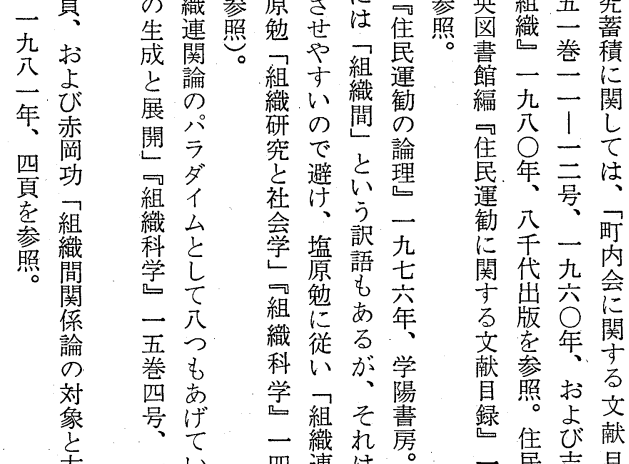
方一心四連は方－底吉目
題立れ論研 る でらが分究。 あ地可野の地 る域能 の好 域 。政な実ま権 治は証し力 論ず研 い構 ので究 伝 造 議あの統論 論る一は以 を。方継来 深 理 法 承 め論とさ理 てとしれ論 い実てると く証生 ベ実 この亦き証 と往れでの が復てあ結 筆をきる。合 者通た。を にじ組そめ 課て織しざ せ組関て し れ織分もき た連析とた 今関に\&地 後視はと域 の角、組 政 課にそ織治 


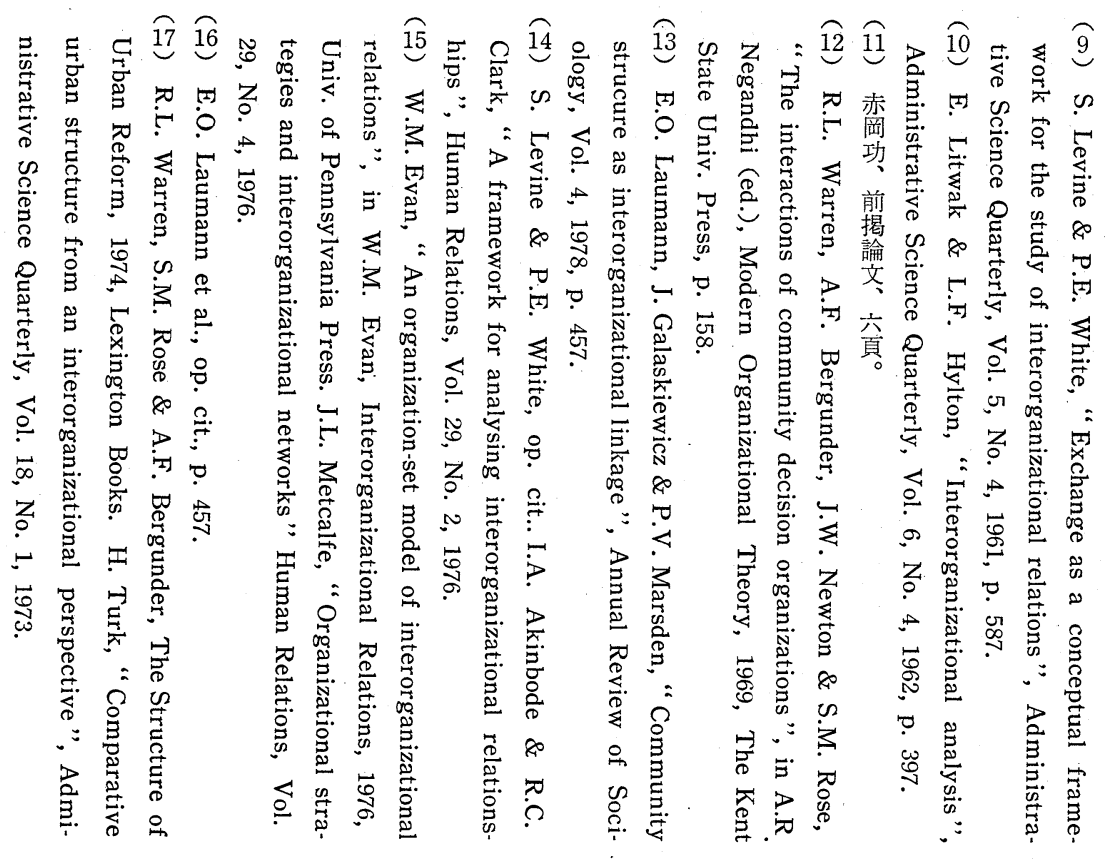

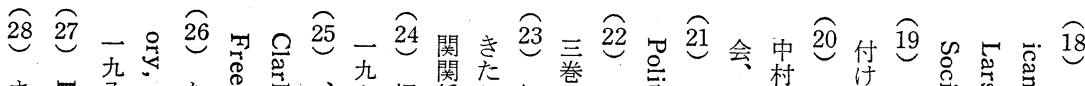

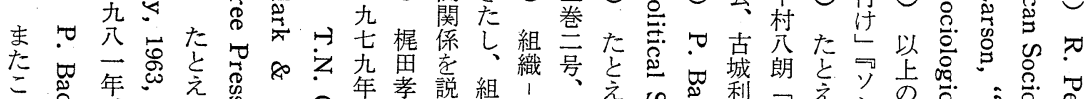

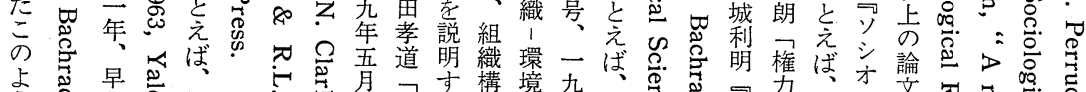

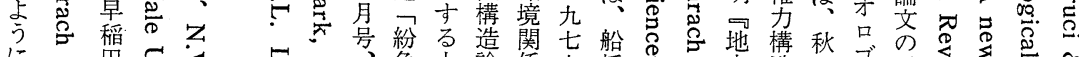

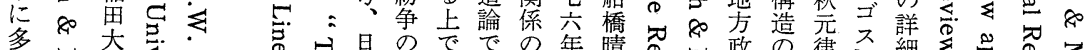

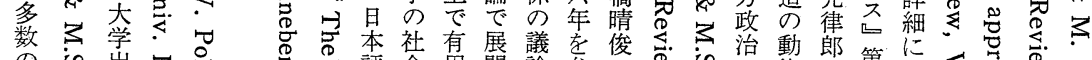

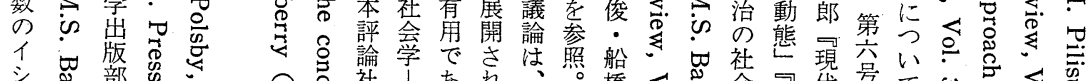
幽部怘心

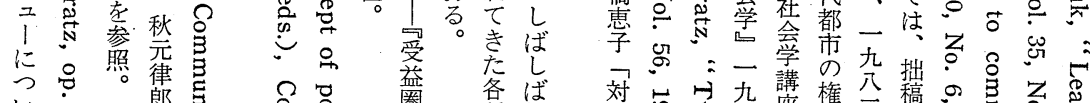

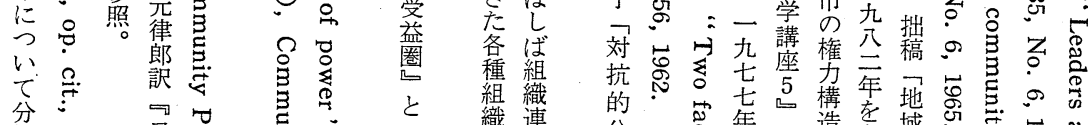

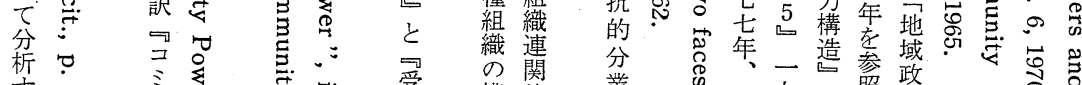

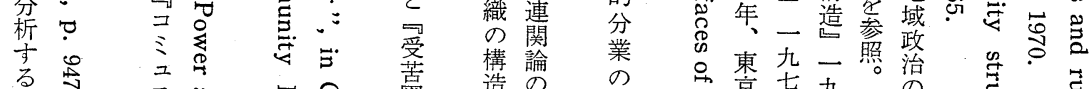

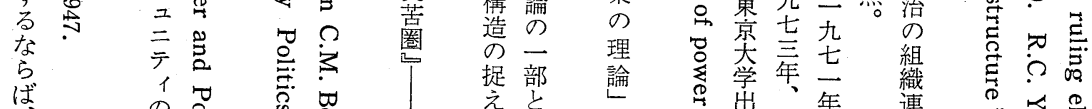

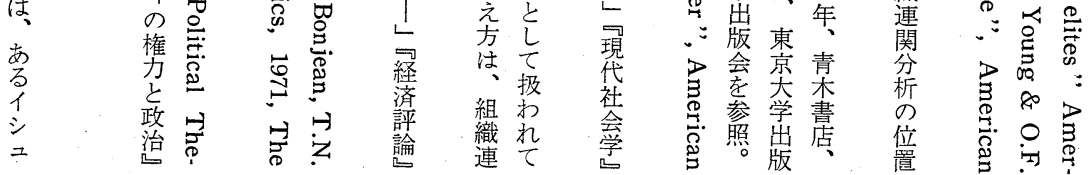




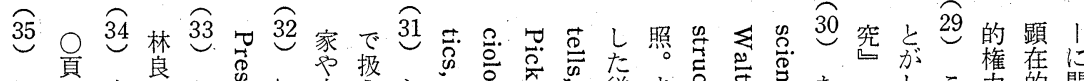

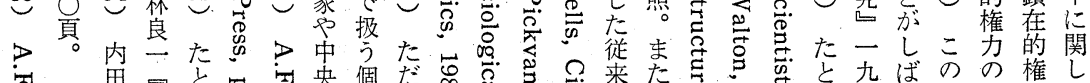

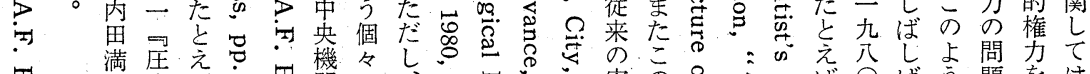

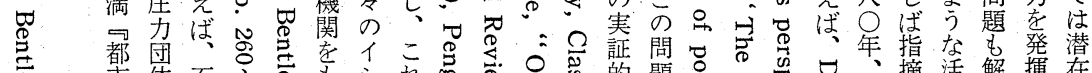

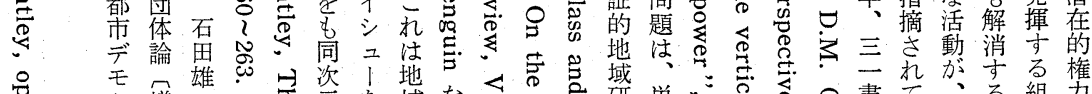

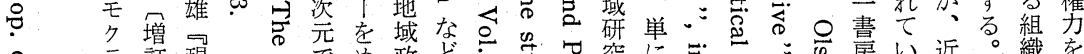

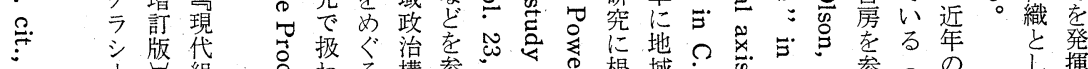

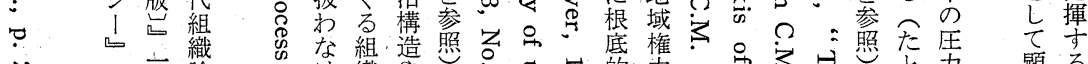

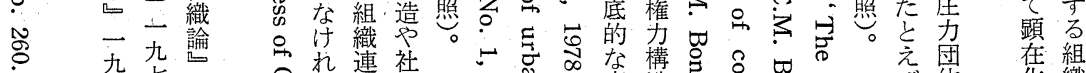

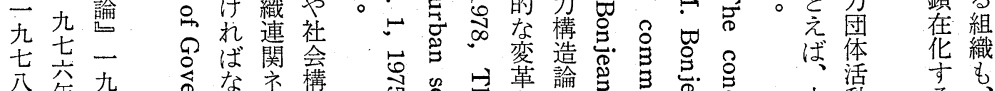

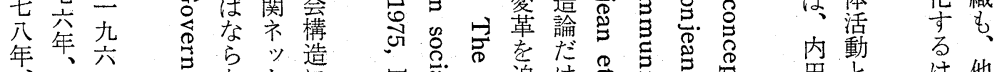

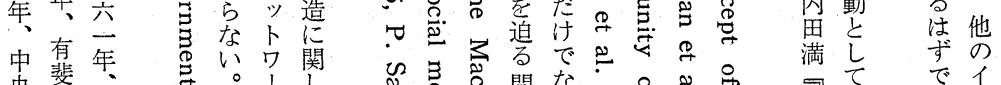

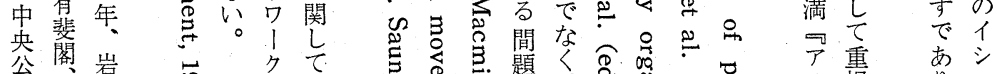

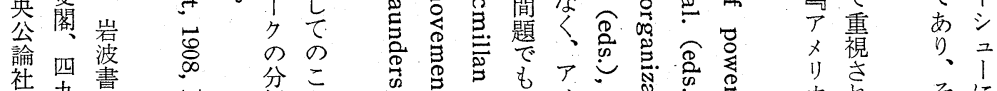

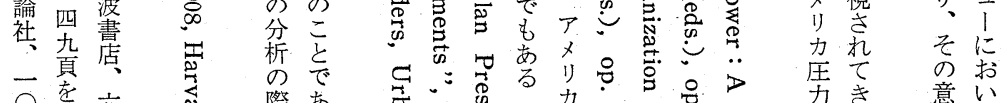

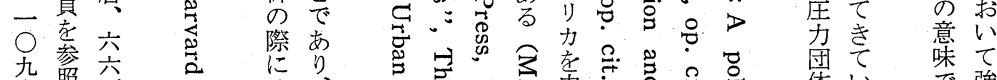

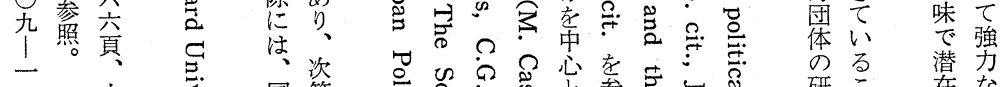

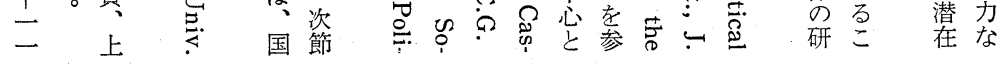

た動

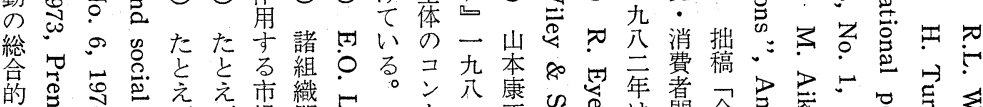

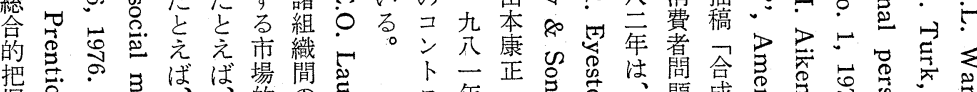

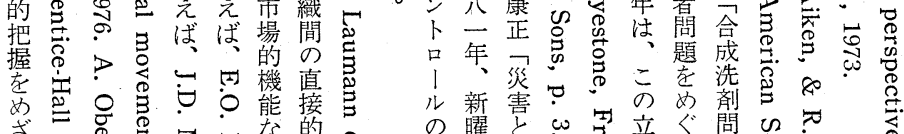

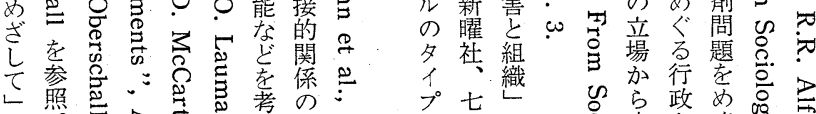

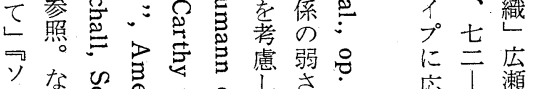

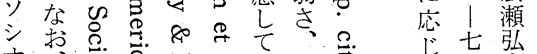

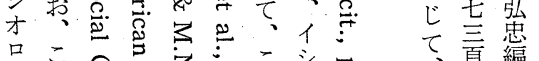

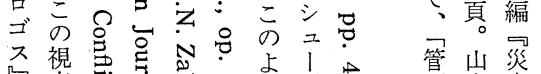

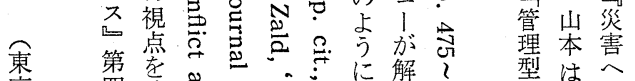

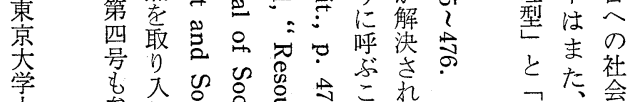

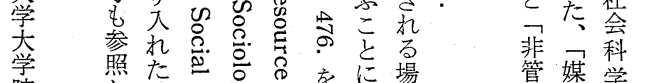

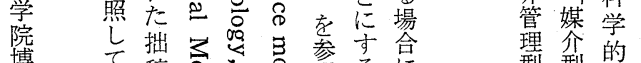

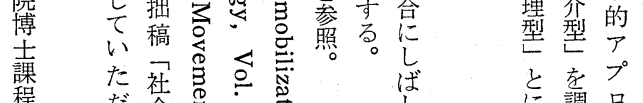

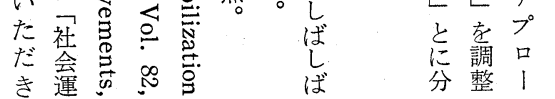

架占政 実 証住る令

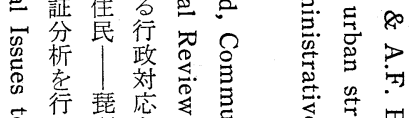

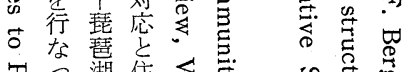
きた湖集导离

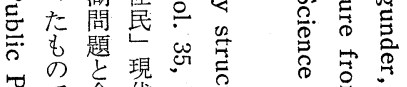

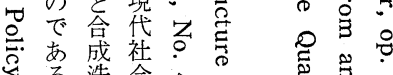
芯先成社

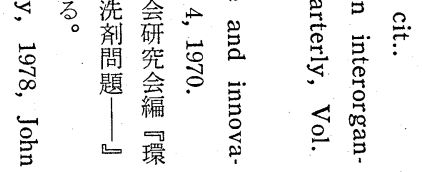




\title{
An Interorganizational Approach to Local Politics
}

\author{
Shinji Katagiri \\ Tokyo University
}

This article argues how we can use a new approach, the interorganizational approach, for the study of local politics. Although the interorganizational approach has been developed mainly in the field of organization study, this approach has been latently used for, and therefore, familiar to the study of local politics as well. In studying local politics, however, this approach has not yet been integrated well and vaguely diversified by several frameworks. In this article, the interorganizational network approach is discussed as the most effective for studying local politics.

Local politics, from the interorganizational network perspective, can be analyzed on any one of the following three levels.

(1) An interorganizational network emerged around a certain issue, which manifests as a discernible phenomenon of local politics.

(2) An interorganizationa! network as a power structure, by which a local political structure is described.

(3) An interorganizational network as an infrastructure, i.e., as a latent social structure, on which local politics is at work.

Among them, the first one seems to be most available, because the analytical objects are distinct and easily confined.

Two axes, (1) existence or absence of a coordinating agency and (2) manifestation or latency of opposition, provide us with four ideal types of "the issue interorganizational network". Those are (1) market-type network, (2) administration-type network, (3) confrontation-type network, and (4) mediationtype network. Some hypotheses are suggested on transitional processes among them, and on decision making process of each type. 